\title{
Synthesis of Prostaglandin $D_{2}$ Receptor Antagonist
}

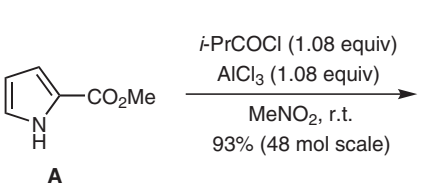<smiles>CC(=O)c1cc(C(=O)C(C)C)c[nH]1</smiles>
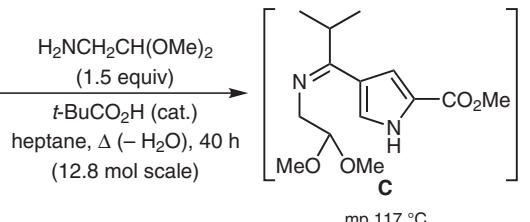

$\mathrm{mp} 117^{\circ} \mathrm{C}$<smiles>CC(C)c1nccc2c1cc1n2CCC1=O</smiles>

$\mathbf{F}$

$\mathrm{mp} 129^{\circ} \mathrm{C}$

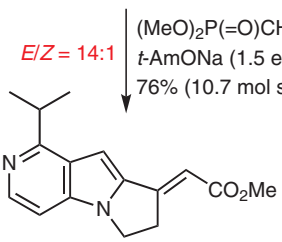

G

mp $137^{\circ} \mathrm{C}$<smiles>CC(=O)C1Cn2c(cc3c(C(C)C)nccc32)C1=O</smiles>

$\mathrm{mp} 203^{\circ} \mathrm{C}$

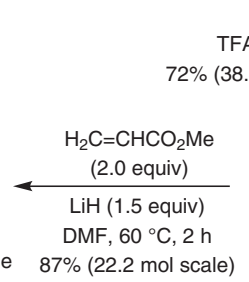

TFA, $60^{\circ} \mathrm{C}, 5 \mathrm{~h}$ $\%$ (38.4 mol scale) $\mathrm{mp} 140^{\circ} \mathrm{C}$
$\mathrm{H}_{2} \mathrm{CO}_{2} \mathrm{Me}$ (2.0 equiv) scale)

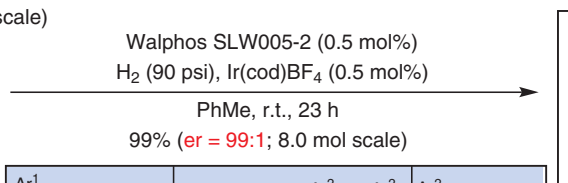<smiles>CC(=O)CC1CCn2c1cc1c(C(C)C)nccc12</smiles>

azaindoles

sulfenylation

asymmetric hydrogenation $\mathrm{Ar}^{1}=$

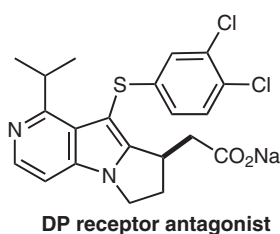

$\mathrm{mp} 389^{\circ} \mathrm{C}$
$\mathrm{NaOH}$ (1.34 equiv) $\mathrm{MeOH}, 50^{\circ} \mathrm{C}, 2 \mathrm{~h}$ $98 \%$ (14.2 mol scale)

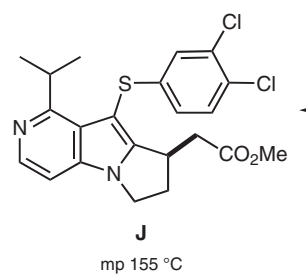

$\mathrm{mp} 155^{\circ} \mathrm{C}$
H

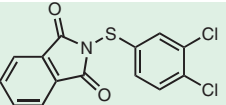

I (1.075 equiv)

$\mathrm{MgBr}_{2}(0.5 \mathrm{~mol} \%)$

DMAc, $90^{\circ} \mathrm{C}, 4 \mathrm{~h}$

$96 \%(8.0 \mathrm{~mol}$ scale $)$
Significance: An efficient kilogram-scale synthesis of the target prostaglandin $D_{2}$ receptor antagonist features a Friedel-Crafts cyclization of an iminopyrrole to generate the azaindole core in $\mathbf{D}$. Key steps are (1) a very efficient asymmetric hydrogenation to install the single stereogenic center $(\mathbf{G} \rightarrow \mathbf{H})$ and (2) a mild sulfenylation using the shelfstable $\mathrm{N}$-arylthiophthalimide $\mathbf{I}$.
Comment: The high er of the hydrogenation was surprisingly insensitive to solvent, but it was sensitive to the $E / Z$ ratio. Thus, batches of $\mathbf{G}$ that contained $9 \%$ of the $Z$-isomer afforded $\mathbf{H}$ in only $81 \%$ ee, whereas batches of $\mathbf{G}$ containing $1 \%$ of the $Z$-isomer gave $\mathbf{H}$ in $96 \%$ ee. The $E / Z$ ratio of the Horner-Wadsworth-Emmons reaction (14:1) could be upgraded to $1000: 1$ by crystallizing the phosphate salt of $\mathbf{G}$.

SYNFACTS Contributors: Philip Kocienski 